\title{
The Strategy of Resistancy and the 'Cultural Hegemony of Transparent Discourse in English-language Translation' RAFEEQ HAMEED AL-OMARY
}

\begin{abstract}
The paper hinges basically on Venuti's notion of resistancy, a strategy which "seeks to free the reader of translation, as well as the translator, from the cultural constraints that ... threaten to overpower and domesticate the foreign text, annihilating its foreignness" (Venuti 305). The orientation of modernist translation towards favouring the domestic over the foreign, the dynamic over the semantic, and the reader-oriented over the author-oriented are highly questioned and argued against in this paper. The stand taken by this paper, however, is not to be mistaken as one that favours literalist translation. The paper seeks to argue in favour of the strategy of resistancy as a new anti-modernist-translation notion in the field of translation theory and practice. This strategy opposes the cultural hegemony of narcissist strategies that promote the obliteration of the uniqueness of the foreign text when translated into the hegemonial Anglo-American English. The paper also attempts to revisit the existing and dominant notions related to the ethics of responsibility and normality in translation as one way to correct the mainstream translational practices and theorising. The paper concludes its statements with further reflections on Venuti's terminological choices, and with some practical mediating suggestions for the promotion of Venuti's notion of resistancy and the advocacy of mutual-respect ethics between cultures.
\end{abstract}

\section{Introductory Remarks}

The strategy of resistancy as a theoretical notion in the field of Translation Studies has risen as anti-Modernist-translation strategy proposed and promoted by Lawrence Venuti in his leading book The Translator's Invisibility: A History of Translation. 
Modernist translation has been the mainstream in English translation theory and practice as an anti-Victorian-translation movement. The Victorians like Thomas Carlyle (1795-1881), Matthew Arnold (1822-68), and Henry Wadsworth Longfellow (1807-82) favoured literal translation and held reverence to it and took it to extremes. Longfellow defending his literalist (I prefer to say 'literalist', though the term is not a vogue in literary translation theory, to indicate the historical load of the term that can be rightly utilised to denote literalism of the $19^{\text {th }}$ century, and think of it as a trend opposing what has come to be known as modernist trend in English translation. Hence literalist versus modernist in terms of, if not English translation criticism, English translation historicism) position in his translation of Dante's Divina Commedia says:

The only merit my book has is that it is exactly what Dante says, and not what the translator imagines he might have said if he had been an Englishman. . . . The business of the translator is to report what the author says, not to explain what he means; that is the work of the commentator. What an author says and how he says it, that is the problem of the translator. (qtd. in Bassnett 70)

The extremeness of such a literalist practitioner is betrayed through the adverb "exactly" in "it is exactly what Dante says." This can be refuted that a literary translation text cannot under any event be the same as an exact copy of its original counterpart: "since to ask for sameness is to ask too much" (Bassnett 28).

Ezra Pound and T.S. Eliot of the twentieth century, on the other hand, came and made a shift toward non-literalist modernist translations. Their attempts have characterised a new trend of translating:

The innovations of the modernist movement provided both the creative impetus and the intellectual foundation for "a modern renaissance in English translation" (Apter 1). Its members, exasperated by what they perceived to be the over-ornamented and reductively literal pieties of Victorian classicists, preferred to view translation as an essentially creative act of transformative identification with the intuited aims of the original poet. (Harrop 90) 
But if modernist translation has occurred to free the English reader of the orthodoxy of the classic shapes and forms and rules of Victorian translation practice, it started to lay down the foundation for new translation theorizing. From the mid-fifties of the twentieth century and onwards translation theory has evolved as a continuum to the efforts of such modernist pioneers as Pound and McFarlane's:

The work of Ezra Pound is of immense importance in the history of translation, and pound's skill as a translator was matched by his perspectives as critic and theorist. . . James McFarlane's article 'Modes of Translation' (1953) raised the level of the discussion as 'the first publication in the West to deal with translation and translations from a modern, interdisciplinary view and to set out a program of research for scholars concerned with them as an object of study.' (qtd. in Bassnett 74)

Reading theorists of the 1960s, 1980s and onwards like Nida, Bassnett, Savory, Toury, New Mark, and many others in the field of English translation theory assures that modernist translation has gained a momentum and been carried on further to extremes as well. The problem is that it unfortunately started to sanctify the extremeness and narcissism of modernist movement in translation theory and practice. The emphasis on the dynamic, the functional, the fluent, and the transformative types of translation has reached the climax where we have started to hear of calls for the "death of the author" of the original literary text and the annihilation of its idiosyncrasies as a foreign text. This is what Venuti has termed and referred to as "Transparent Discourse."

\section{Pro-Transparent-Discourse Extreme Theories:}

Most of the translation theories so far existing in the field of translation studies do give priority to target-text-oriented strategies and propagate ethics that favour such strategies and promote the cultural hegemony of transparent discourse in English-language translation as opposed to the strategies that seek to emphasise the foreignness of the foreign text. Most of the theoretical writings so far existing like those by Susan Bassnett, Gideon Toury, and many others in the field of translation theory seem to have obvious prejudice against translational theories that support the foreignness of the foreign text as part of the culture that created it and the 
literary system in which it has evolved. Two extreme modernist notions are taken as examples here, and briefly revisited so as to reveal the extremeness of the transparent discourse in modern translation theory:

\section{1- $\quad$ Bassnett's Statement on 'Moral Responsibility in Translation'}

It was good of Bassnett to discuss different approaches to translation in her leading book Translation Studies that was first published in 1980, and republished revised in 1991. Regardless of her realisation of the different approaches to translation, Bassnett could not be but a theorist who has favoured the transparent discourse, a discourse that tries to belittle the other discourses that are guided by responsibility toward the source text and its culture. She antagonistically declares:

To attempt to impose the value system of the SL culture onto the TL culture is dangerous ground, and the translator should not be tempted by the school that pretends to determine the original intentions of an author on the basis of a selfcontained text. The translator cannot be the author of the SL text, but as the author of the TL text has a clear moral responsibility to the TL readers. (Bassnett 23)

If moral responsibility is defined in reader-oriented terminology, the authenticity of the translation text can never be established. It would certainly be lost, either totally or partially, on all the linguistic, literary and cultural levels, let alone the ethical ones. It is under such reversed ethics that it "seemed as if many mediocre writers had discovered, and were exploiting, the regrettable fact that indifferent translation is easily achieved and is able to satisfy a multitude of uncritical readers (Savory 45). Emphasis is to be laid here on Savory's terminology. The notion of indifference and that of exploitation already show strict opposition against the extremeness of Bassnett's notion of target-oriented sense of responsibility. When the source text is neglected, it is sure that translators would enjoy their fancies and start to produce texts that cannot be but indifferent and exploiting, let alone being far from being as authentic enough as to be classified as real translations. 
In his book Descriptive Translation Studies and Beyond Toury presents his views on the position of translations in a target system. He calls for the "reversal of roles" where a target text is assumed to be original in the hosting culture. Based on this view, he gives little importance or none at all to the source text with regard to any critical study or research into the textual-cultural features of the new text that has been transferred through time and space to settle in another culture. We listen to him speaking in a tone that manifests changing of roles and rules of normality:

while translations are intended to cater for the needs of a target culture, they also tend to deviate from its sanctioned patterns, on one level or another, not least because of the postulate of retaining invariant at least some features of the source text - which seems to be part of any culture-internal notion of translation . . . ; it is not unusual for a certain amount of deviance to be regarded not only as justifiable, or even acceptable, but as actually preferable to complete normality, on all levels at once. (Toury 28)

Toury's postulations are in fact part and parcel of the so-called "poly-system theory" in Translation Studies and are the seeds for what is now called the "deconstructionist translation theory." The poly system theory is a theory that looks at translations as independent and facts of the target culture alone: Whether translations are pseudo-translations or genuine, direct or indirect, they constitute (sub-) systems in their own rights within the linguistic, literary and cultural systems of the receiving culture. Toury speaks of "normality" the other way around. When we are supposed to think of deviations from the perspective of the source culture and its systems, he speaks of deviations from the target culture and its systems. If the target text retains "some"[I doubt such theory would accept a translation if it retains most] of the features of the source text, this is "to be regarded not only as justifiable, or even acceptable, but as actually preferable to complete normality" (ibid. 28). This talk betrays the extremism into which the transparent discourse has evolved in translation theory, let alone the deconstructionist element contained in it. 


\section{The Strategy of Resistancy as Anti-Transparent-Discourse in Translation}

The transformation of modernist theory into some forms of post-modern theorization in translation like the theory of deconstruction that has been promoted by Jacques Derrida has been one of the vital driving forces behind the emergence of anti-postmodern movement in translation. The flow of political globalization in one direction as to serve the Anglo-American scenario has again been responsible to a good degree to form the basis for antagonistic attitudes and the rise of new politics resistant to the new ethics propagated by modernist and post-modernist translation theory and practice. Anthony Pym, in his article, "Globalization and the Politics of Translation Studies," has focused on such hegemonial dimensions and the need for resistant attitudes:

In recent years the United States has virtually done away with any pretense to international law. Treaties have been revoked, wars have been initiated on the weakest of excuses, international human-rights conventions are violated on a daily basis, international courts are seen as fine ideas only for as long as no US citizen will be subject to them. Translation is an essential element of the institutions that are thus being flouted. When right is decided unilaterally, without need for consultation or negotiation, or when the consultations and negotiations are simply ignored because they do not reach the right conclusion, then the need for translation is obviated and our object of study will indeed serve little purpose. That scenario is to be resisted. It is not to be mapped onto the inevitabilities of globalization.

To be even blunter: in our small academic political acts, we have before us at least two possible models of contemporary empire. One, in Europe, incorporates translation into its very principles, becoming what one analyst calls the world's first postmodern and potentially cooperative empire (Cooper 2003: 78-79). The other, in the United States, ignores many of the virtues to which translation might hope to contribute, remaining modernist in its insistence on nation. The first kind of empire gains admirable flexibility, defending its borders by extending them, just as its weak inner identity makes it unsuited to any risk-ridden action in the world. The second kind of empire has the unity and force needed for action; it provides international relations 
with its only real hope of power-based stability; yet it sadly underrates the diversity of human cultures. (753)

These statements by such a resistant translation scholar represent the reality of Translation Studies today. Such realities could not have passed unnoticed by many other translation theorists, scholars and practitioners everywhere in the world especially those coming from third world cultures that were politically dominated by the Anglo-American culture for long. Post-colonial theories in translation have also helped in the emergence of many critical voices that have been effective in creating the necessary awareness towards the dangers of the Anglo-American hegemonial modernist and postmodernist discourses in translation:

A close examination of some of the translated texts of the Orientalists clearly establishes the colonial implications of such translations. What becomes apparent is the desire to "purify" Indian culture and to speak on its behalf since Indians were unreliable interpreters of their own history and culture. William Jones thus undertook a massive enterprise of translating the Sanskrit literary texts, Arabic texts on law, and Persian texts on grammar. The message was quite clear that he was retrieving these texts for a double purpose: to teach the Indians to better understand the value of their own texts and to further the Orientalists' concept of the orient. (Abu-Mahfouz 4)

Similarly, critics from different parts of the world practically started to respond by the propagation of translational strategies that give reverence to the foreign text's literary, linguistic and cultural aspects. And if the calls to transform the original text in translation helped in the creation of what we may, to agree with Venuti, call "the hegemonial transparent discourse" in English translation, the opposing calls, though limited, have been bringing change both in theory and practice. Venuti's call for the strategy of resistancy in translation has come in its time to redirect translation theory and practice and to open the world for new ethics of translating foreign texts in English. Venuti's call for the strategy of resistancy defended by this paper is not to be misunderstood as a call back to literalist translations of the Victorian age. It is an ideological modern call to respect the foreign text and ethics of mutual globalised discourses. 


\section{Concluding Remarks}

As is always known and understood, the rise and fall of terminologies and the consequent conflicts between them in the field of translation studies reflect real opposition and disagreement between theorists and practitioners in the discipline. Such opposition is clearly reflected through the binaries that are one of the distinct features of Translation Studies. Dichotomies such as dynamic-formal, communicative-semantic, endocentric-exocentric, content-form, covert-overt, reader-oriented and author-oriented and many more tend to say almost the same thing though with more or less different emphasis. Likewise, the terms transparent or even fluent promoted and utilised by Venuti seem to form a good dichotomy with the term accurate. In fact, the latter two terms are traditionally confronting one another in translation theory. Yet, Lawrence Venuti uses the term "resistant" as opposed to "transparent." And we must have noticed the spelling of the noun with ' $y$ ' that replaces the ' $\mathrm{e}$ ' in the word 'resistancy.' This unusual spelling, which I completely agree with, seems to express the unusual translational trend that Venuti advocates. Venuti throughout his book is aware of the dominance of modernist translation and its ethics of transparent discourse within the Anglo-American culture. He knows that he is bringing a new line of theory that is certain to provoke the proponents of the prevailing current of thought in Translation Studies. This new terminology is sure to bring such a new ideological emphasis as to indicate the hegemonial discourse in English language translation, which he strongly opposes: we also can clearly notice the opposition between transparency and resistancy in the following passage:

A translated text should be the site where a different culture emerges, where a reader gets a glimpse of a cultural other, and resistancy, a translation strategy based on an aesthetic of discontinuity, can best preserve that difference, that otherness, by reminding the reader of the gains and the losses in the translation process and the unbridgeable gaps between cultures. .. . Now more than ever, when transparency continues to dominate Anglo-American culture . . ., it seems important to reconsider what we do when we translate. (Venuti 306) 
Again, the term "resistant," Venuti uses has a good address to translators to oppose the hegemonial practice and canons that deny their rights and visibility:

Translators must also force a revision of the codes - cultural, economic, logical - that marginalize and exploit them. They can work to revise the individualistic concept of authorship that has banished translation to the fringes of AngloAmerican culture, not only by developing innovative translation practices in which their work becomes visible to readers, but also by presenting sophisticated rationales for these practices in prefaces, essays, lectures, interviews. (Venuti 311)

Such resistant calls should be respected. Venuti does not go back to discuss the translational notions in opposition. He has preferred to look at translation from an ideological perspective in a world that is marked by globalisation. He has realised the hegemonial acts of translators and translation theorists that have gone to the extreme where the foreign text is domesticated instead of being foreignised, excluded instead of included, obliterated instead of introduced. The need to free the foreign text from such hegemonial practices becomes urgent worldwide. The following suggested mediating forms of resistance can be effective as to help in reorienting the existing dominant thought in translation theory and practice:

1. Redirecting the notion of moral responsibility in translation towards both the author of the text and its context, the globalised reader (the searcher of the other), and the concerned literary critics (such ethics have been discussed in detail in a paper presented at the $37^{\text {th }}$ All India Conference of Dravidian Linguistics, 18-20 of June, 2009, and got published in MAJELL, a refereed journal published by the Department of English, Maulana Azad Urdu National University; see references below).

2. Appealing to new type of international readership in English through translations that respect any readable style of the receptor language without damaging the foreign text's idiosyncratic characteristics under any slogans. There is a need to fuse the dynamic with the semantic by the power of the right textual interpretation of the text, yet in the light of the context of its producing culture. 
3. The right utilisation of globalizational technology like the internet. This can be achieved only by the promotion of awareness of proper resistant approaches that seek to propagate the foreign cultures and their exotic dimensions in a way that guarantee mutual understanding and respect.

All in all, theoretical extremeness is not a solution; narcissist strategies are a form of deception; and hegemonial discourses destroy rather than build. Ethics of respect are to be applied in translation theory and practice as one way of opposing extremeness, narcissism and hegemonial discourses.

\section{Works Cited}

Abu-Mahfouz, Ahmad. "Translation as a Blending of Cultures." Journal of Translation 4.1 (2008): 1-5, SIL International. Web. 22 June 2010.

<http://www.sil.org/siljot/2008/1/51140/siljot2008-1-01.pdf >.

Al-Omary, Rafeeq Hameed K. "The Strategy of 'Omission' in Literary Translation and Translating: Questioning Validity." MAJELL 2.1 (2010): 1-21. Print.

Bassnett, Susan. Translation Studies. London and New York: Routledge, 1991. Print.

Pym, Anthony. "Globalization and the Politics of Translation Studies." Translators' Journal 51.4 (2006): 744-757.Web. 26 June 2010. < http:// www.tinet.cat/ apym/online/translation/globalization_canada.pdf>

Savory, Theodore. The Art of Translation. London: Jonathan Cape, 1968. Print.

Toury, Gideon. Descriptive Translation Studies and Beyond. Amsterdam: John Benjamins, 1995. Print. Benjamins Translation Library 4.

Venuti, Lawrence. The Translator's Invisibility: A History of Translation. London and New York: Routledge, 1995. Print. 


\section{References}

Harrop, Stephe. "Ezra Pound's Women of Trachis: Modernist Translation as Performance Text." Platform 3.1 (n.d.): 90-106. Web. 23 June 2010.

<http://www.rhul.ac.uk/drama/platform/issues/Vol.3No.1/Pound.pdf>.

House, Julian. A Model for Translation Quality Assessment. Tubingen: TBL Verlag Gunter Nar, 1977. Print.

Nida, A. Eugene. Toward a Science of Translating. Leiden: E.J.Brill, 1964. Print.

Pym, Anthony. "Complaint Concerning the Lack of History in Translation Histories."

Livivs 1 (1992): 1-11, HISTAL.Web. 27 June 2010. <http:/ / www.tinet.cat/ apym/online/research_methods/complaint_history.pdf $>$. 